\title{
THE LEGAL RELATIONSHIP BETWEEN THE SURGEON AND THE ANAESTHETIST ${ }^{1}$
}

John H. HaRland, M.B., E.Ch., ${ }^{2}$ and Alan W. MeWett, LL.B., B.C.L., LL.M., S.J.D. ${ }^{3}$

THE RELATIONSHIP existing between the surgeon or the anaesthetist and the patient is fairly well defined from the legal point of view. This is well described in several sources readily available (1-6).

In a leading paper on the medico-legal aspects of anaesthesia (7), it is stated: "Prior to 1942, when a precedent was set in Ontario, the surgeon was considered to have full charge in the operating room, which included the anaesthesia. The legal master-servant relationship existed between the surgeon and anaesthetist." (Italics supplied.) The italicized sentence indicates that the surgeon had vicarious responsibility for the actions of the anaesthetist. We doubt that this statement is a correct interpretation of Ontario Law, prior to 1942, but it represents the point of view of a person whose views must be listened to with respect, and a concept which would be readily approved of by many other authorities. It forms, in any event, a starting point in studying this interrelationship.

\section{Direct Responsibitity to the Patient}

The same legal principles apply to the relationship of the surgeon and the patient, the anaesthetist and the patient, and the patient and any person who undertakes to look after a patient, and actually does so. They may not thave to undertake the task, but once having done so, they owe a duty of care to bring to the task the requisite skill and knowledge, and to perform it with a fair and reasonable standard of care and competence ( 1 ).

The relationship is only established when there has been a true assumption responsibility, but once this exists, a duty of care is created. It must be remembered that this duty is just as valid where the services are rendered gratuitously, as where they are carried out for reward. The relationship may arise from a written contract, but more often arıses independently of an express written contract.

Thus, it can be said that surgeon and anaesthetist both develop, independently of one another, a direct responsibility to the patient. If one person owes a direct duty of care towards another, he cannot escape his own responsibility by delegating this duty, or any part of it, to another person, no matter how competent the latter may be. As Lord Justice Denning put it: "When a person is himself under a duty to use care, he cannot get rid of his responsibility by

\footnotetext{
1Originally presented at the meeting of the Western Division of the Canadian Anaesthetists' Society, March 19-21, 1959, Saskatoon.

${ }^{2}$ Chnical Instructor, Department of Anaesthesia, University of Saskatchewan College of Medicıne and Unıversity Hospital, Saskatoon.

${ }^{3}$ Associate Professor, College of Law, University of Saskatchewan.
} 
delegating the performance of it to someone else... . to a servant under a contract of service, or to an independent contractor under a contract for services" (8).

\section{Vicarious Responsibility to the Patient}

The doctor's responsibilities do not end with what he does with his own hands. He can be held liable for the negligent acts of his subordinates, provided he has the right to control the manner in which they carry out their duties. This is the doctrine of respondeat superior The subordinate in such a case is called a "servant," in the legal sense, and the adjective "vicarious" applies to this indirect liability of the principal. "It is also important to remember . . . that the principle of respondeat superior is not ousted by the fact that a "servant" has to do work of a skilful or technical character, for which the servant has special qualifications" (Lord Justice Somervell) (8).

The master may be liable even where he would lack the skill to do the servant's task himself. As put by Denning: "The reason why the employers are liable in such cases is not because they can control the way the work is done-they often have not sufficient knowledge to do so-but because they employ staff and have chosen them for the task, and have in their hands the ultimate sanction for good conduct-the power of dismissal" (8)

It must be remembered that, although the subordinate has a legal master, this does not free the servant of his own direct duty to the patient, or from his own liability for any breach of that duty Indirect duty arises independently of direct duty and one person may owe to another both types of duty concurrently. The distinction between direct and vicarious responsibility is an important one and crucial to the subject under discussion.

\section{Two Doctors with a Common Patient}

Two physicians with one patient can be related in a number of ways. First, they may be independent and co-equal, neither being tesponsuble for the negligent acts of the other, in which case they might be referred to as "persons with a common purpose." Second, if it happens that they are business partners, each is jointly and severally liable for the negligent acts of the other. Third, if one is able to control the manner in which the other does his work, for example, a salaried assistant, the subordinate is the legal servant of the other. Fourth, one may be subordinate to the other, but not his legal servant. He is then termed an "independent contractor."

\section{The Master-Servant Relationshup}

The principle of respondeat superior means that the rnaster is vicariously liable for the negligent act of his servant. $\mathrm{He}$ is not liable for the negligent act of his independent contractor unless he has delegated his own direct duty to such an independent contractor.

The distinction between servant and independent contractor is not absolutely 
clear cut, but for our purpose it may be said that the independent contractor can be told what to do, but not how to do it; the servant can be given orders regarding both. The difference lies in the right of control of the master over the servant's actions. Failure to exert right of control does not relieve the master of vicarious responsibility.

The servant or the independent contractor is not ordinarily responsible for negligent acts of the master, but under certain circumstances his duty as a reasonable man might require him to draw attention to an error of the principal.

It was stated, in the paper quoted in the introduction, that the master-servant relationship existed in the general case of surgeon and anaesthetist, prior to 1942 , in Ontario. In reality, however, the existence of such a relationship would have depended entirely upon the facts of each case coming to trial.

It will be seen as we proceed that the law in American jurisdictions, as it relates to master and servant, is at variance with Canadian concepts, in minor regards In several states, the doctrine of the "borrowed servant" is applied. This is a discarded principle of British law in the area we are considering $(8,9,10)$. In at least one state, "If the master in fact derives no profit from the employment of the servant, he is not liable for the servant's torts. On this reasoning, charitable institutions, such as hospitals, have been exempted from the ordinary rule of master and servant liability" $(11,12)$.

\section{The Concept of Negligence}

It is not intended to examine the legal concept of negligence in any detail in this paper. It must be remembered that it does not merely mean carelessness, but "connotes the complex of duty, breach and damage thereby suffered, by the person to whom the duty was owing" (1). For our purposes, negligence may be regarded as a breach of duty owed by one person to another, with resulting damage to the latter.

Anyone who undertakes a task, such as a surgeon performing an operation, or an anaesthetist ${ }^{4}$ administering an anaesthetic, also undertakes to perform the task in a reasonably diligent and careful way. What is "reasonably careful" depends entirely upon the factual circumstances of the individual case. Among the factors which the court will take into account, we may mention the delicacy of the task, the general standards of knowledge among the profession, the fitness of the individual to undertake that particular task, and so on. The question is usually put in some such way as: "would the ordinary man, in view of the crrcumstances, say that the clefendant had acted in a reasonable and careful manner." Fallure to perform the task with the requisite standard of care is a breach of duty towards the plaintiff, and if damage results from that breach, the tort of negligence will have been committed. (For discussions of the nature of negligence, see the following references, $1,2,3,4,5,6$.)

4The word "anaesthetist" is used throughout to indicate a physician anaesthelıst This is the preferred practice in Canada, as in Great Britain Where the word occurs in judgments, i is spelled as it appears in the original. The term "anesthetist" imples "nurse anesthetust"; ir the United States, where the preferred term for a physician anaesthetist is "anesthesiologist." 
It is perhaps worth mentioning that it will not necessarily be a valid defence to plead that one had done some procedure in a certain way, and that previously no harm had come of using that particular technique. "Neglect of duty does not cease by repetition to be neglect of duty," as Lord Tomlin put it (1), or as Jhrased by Justice Doyle: "Methods employed in any trade, business or proSession, however long continued, cannot avail to establish as safe in law, that which is dangerous in fact" (13).

In a few of the cases, which will be cited, the plaintuff has based his action upon a technical assault, that is a trespass upon his person. Any intentional touching of a person, without his consent, constitutes an assault. The plaintiff must show that the acts of the defendant went beyond the consent which the plaintiff gives for the touching necessary for the due performance of the operation. This may be difficult for the plainteff to prove, but it does have the advantage of relieving the plaintiff of the burden of proving lack of reasonable care which is necessary in an action in negligence.

\section{Precedent}

Every case tried could be said to form a precedent. However, the points of law brought out are mostly repettive and in the average situation there will be a few leading cases which are referred to as authonty. Common law is based on precedent. A decision of a superior court on a point of law, once made, remains binding on any lower court, and in some cases upon that court or a court of equal jurisdiction.

In Canada, this principle operates only within the judicial system of the province, unless the case is appealed to the Supreme Court of Canada. Relevant decisions in other provinces and Great Britain, particularly where the matter concerns some point of law never previously decided, are merely highly persuasive. Decisions from other jurisdictions, such as other parts of the Commonwealth or the United States, are persuasive to a lesser degree

It is often a matter of annoyance to the physici nn that when he asks his legal adviser as to the best manner to act in a particula- situation, he does not receive a clear-cut answer. In regard to this it must be remembered that "The Law' is not a body of systematised rules, enacted as a whole and fixed for all time. Judges have always exercised the power of developing the law, and this is now recognized to be a proper part of their function" (14). Thus the lawyer can only proffer advice. He cannot guarantee that following this advice will ensure against an action.

\section{The Practicality of Redress}

When several people are looking after a patient, he may be injured by the negligent act of one of them. When the patient has been rendered unconscious it may afterwards be impossible for the plantiff to say exactly which of the defendants was actually responsible.

This sort of group situation offers considerable difficulty in malpractice trials For a discussion of the applicability of the doctrine of res ipsa loquitur and the principle of absolute liability, see references $1,3,15$, and 16 . 
The leaning of Canadian and British law is towards the idea that because an accident happens and damage is thereby sustained, this alone does not mean that someone must pay for it. As put by Lord Justice Scott, "The standard of care which the law requires is not insurance against accidental slips. . . . It is not every slip or mistake, which imports negligence" (17).

On the other hand, in at least two American decisions, the view seems to have been taken that since damage had been sustained the injured party should be able to recover, and with that in mind it was ruled that the operating surgeons were responsible for the negligent acts of those working under them $(16,18)$.

The law is not anxious that a state of affairs shall arise where the only remecy the injured person has is against an impecunıous person from whom adequa:e recovery would be impossible. In some states, state-operated institutions cannot be sued. Such protection is called "sovereign immunity," since it is based historically on the concept that "the King can do no wrong." In some jurisdictions, "non-profit" charitable institutions enjoy simular privileges (11). In such jurisdictions, there may be a tendency to find the operating surgeon liable for the negligence of a hospital employee, whose general legal master, the hospital, enjoys immunity.

\section{The Anaesthetist as Legal Servant of trie Surgeon}

The idea of the anaesthetist as the surgeon's legal servant could have arisen because of some general and some specific legal reasons. Among the general reasons, one might unclude the following points.

1. The anaesthetist is historically a newcomer in the domain of surgery, and he owes his existence as a specialst to the increasing complexity o modern surgery and anaesthesia.

2. 'The patient has most usually sought out the surgeon himself or has been referred to him by another practitioner-by virtue of the reputation enjoyed by that surgeon. Only under exceptional circumstances will the patient specify or engage a particular anaesthetist on his own initıative. The only persons who take an active interest in this are doctors and their families.

3. The patient is primarily submitting himself to operation for benefit expected from the surgical procedure. The anaesthetic is therefore only a secondary consideration to him.

4. In the past, and to some degree today, the surgeon chose the anaesthetist himself. In some instances chorce depended not on ability, but on willingness to comply with the surgeon's wishes. In the days when the surgeon paid the anaesthetsst himse $f$, he might have been the legal master of the anaesthetist. In Canada, today, hcwever, this practice would be corsidered as fee-splitting, and hence no longer occurs.

In most jurisdictions in the United States, the surgeon is considered to control and supervise the actions of the nurse anaesthetist. The nurse is not considered to be engaged in the practice of medicine. "They are but carrying out the orders of the physicians to whose orders they are subject. The surgeon has the power and therefore the duty to direct the nurse and her actions during the operation" (Chief Justice Waste of the Supreme Court of California) (19). 
Even though the surgenn does not employ the nurse, and even though the hospital, rather than the surgeon, bills the pdiient for the anaesthetic, the surgenn may still be held liable under the "borrowed servant" doctrine. It may be mentioned, parenthetically, that in some United States jurisdictions, unlike Canada, corporations can legally practise medicine. It is considered that the hospital lends the nurse to the surgeon. As quoted in one judgment (16): "Where a servant has two masters, a general and a special one, the latter if having the power of direction and control is the, one responsible for the servant's negligence." See also the following cases, 15, 16, 20, 21.

Turning to cases where a physician anaesihetist was roncerned, we will consider first an English decision of 1909, the Hillyer case. Durng an examination under anaesthesia, a patient's anns were allowed to hang over the sides of the table. One was burned on a hot water can, while the other sustamed a nerve injury from being pressed aganst the table. The patient sued the hospital board. The action failed. The Court held that the surgeon rather than the hospital was the legal master of the hospital employees in the operatıng room, albet temporarily, and hence the surgeon was vicarıously liable for their negligent acts (22).

The relationshup between the surgeon and the hospital-employed nurses and porters was very thoroughly exammed. The Court stated that although the nurses and orderlies were servants of the hospital, "Once the doors of the operating room close behnd them, the surgeon is supreme."

The relationship of the surgenn to the anaestheiisi was not considered, but it may be discerned that, at that inie and place, it was not thought any bismess of the "arministrator of anaesthetics" to concern himself with the posture of, or prevention of injury to, the patient

The "surgenn supieme" 1dea is essentially the sane as the borrowed servant doctrine In this case, it did not apply to the anaesihetıst. However, between this decision in 1909 and the English decisions which overruled the principle $(8,9)$ in 1942 and 1951, the surgeon could conceivably have been held liable for the anaesiheiist's negligence, provided the latter was a hospital employee. Although there was a time in Canada when anaesthetists were employed by huspiids, to our knowledge the princunle of Hillyer's case was never applied in this way, eilier in this country or in its country of origin.

In an English decision of 1952 (23), a surgeon was found to have been 80 per cent responsible for an anaesthetic fatality, the anaestheiisi only 20 per ceni. An out-patient was given mitrous oxide by mask, prior to the dehridement of burns. He became hypoxic and unco-operative. It was then realized ihai some other technique would be necessary, particularly since the burns were on the face. Pentothal was given intravenously, with a fatal result. The surgeon was a resident, qualified two years; the anaesthetist was a junior iuien qualified a few munth. They were working unsupervised. In this connection, it must be remembered that, at indi time in Fngland, a physician became a registered practitioner immediately upon gradiation. Ncrcrtheless, in the judgmeni, the Court castigated the hospital authorities for allowing inexperienced persons to undertake work of this nature. 
Apparently the surgeon was in charge of out-patient anaesthesia; furthermore, he made the decision as to the anaesthetic technique. Lord Justice Denning said:

I find it very difficult to place much blame on Dr. W. [the anaesthe1sst]. She was not in charge of the operation, Dr. S. was. Moreover, he was in his own words, "responsible for the administration of anaesthetrcs." He decided to use nitrous oxide. That was the first mistake, or at any rate the cause of all the trouble. Then they decided to use Pentothal ... She adminstered the Pentothal under his very eyes and with his entire approval Under these circumstances, it seems to me that her share in the responsibility is very much less than his.

So far as we are aware, this is the only instance of a surgeon being held liable for a clear-cut anaesthetıc fatality when the anaesthetist was another physician. It will be seen that the surgeon had the right to control, and did control, the actions of the anaesthetist to a very unusual degree. Such crrcumstances are very unlkely to be reproduced in Canada.

In a British Columbia case of 1951, it was alleged that injury had followed a brachial block $(24,25)$. Application was made to bring suit against the surgeon, staff anaesthetist, and resident anaesthetist for technical assault. It was held that there was no evidence of neglgence in giving the block and that no assault had occurred. However, it was postulated by the Court that had the surgeon engaged the anaesthetsst, and had the latter been negligent, the surgeon might have been liable No decision was made on this point

In a California case, in 1944, the Court considered the suit of a patient who sustained a brachial neuritis, owing to a shoulder brace (15). The patient sued the family doctor, the surgeon, the doctor owner of a private hospital, and the physician anaesthetist employed by the private hospital. Chief Justice Gibson said: "Although the assisting physicians and the nurses may be employed by the hospital, or engaged by the patient, they normally become the temporary servants or agents of the surgeon, while the operation is in progress and liability may be imposed upon him, under the doctrine of respondeat superior"

A 1957 appeal before the Supreme Court of Colorado is interestung (18). It followed a mishap in Colorado Springs, a few years earher. The surgeon entered the operating room and gave directions to the orderly as to the positioning of the anaesthetized patient. On the surgeon's request, the orderly went to fetch a strap. The surgeon turned to have his gown tied The anaesthesioloigst turned around to make chart entries, and at this point, the unattended patient fell off the table, sustaining injury. Subsequently, the surgeon, anaesthesiologist, and orderly were joined as co-defendants. A jury found the surgeon wholly liable. This verdict was considered reasonable and upheld by the appellate court. Justice Day said in his reasons for judgment: "Under the admittedly complex activity in an operating room, it cannot be stated as a matter of law, the exact moment at which the responsibility of the surgeon begins. It is not a matter of law when the sole resionsibility of the hospital ends and the surgeon's responsibility begins or superseces it. These are questions of fact. The surgeon cannot arbitrarily fix the time at which his responsibility begins. His actions set the time."

He also said: "As to Dr. B. [the anaesthesiologist] under the instructions and the evidence, the jury could find that the anesthetist was not required to give 
personal attention to the safety of the patient, since she was charged with the responsibility of chart and record keeping. Apparently the jury did so find."

The Court also said: "If, however, the concurrent negligence of two or more persons combined, results in an injury to a third person, they are jointly and severally liable, and the injured person may recover from either or all. The concurring negligence of one is no excuse or defense to the other. . . . the surgeon owed a legal duty to his patient, which he farled to discharge, and such failure constituted the negligence found by the jury."

An appeal heard by the Supreme Court of Kansas, in 1953, reveals a story of clinical as well as legal interest (26) The plaintiff had had an emergency laparotomy. The anaesthetist was a doctor, but whether he was a resident, a practitioner, or a specialist is not apparent from the judgment. For 36 hours after operation, the patient was unable to speak or swallow. Eventually, when she developed cyanosis, an otolaryngologist was summoned. He examined the patient and removed from the larynx a Lumbard oral airway. As recorded in the judgment, the E.N.T. surgeon "held the airway up and said 'Charley [the defendant surgeon], this thing should never have happened.' $\mathrm{He}$ then put the airway on the bed.... [and] said, 'I have heard of a lot of things, Charley, but this is the first . . . time I have ever seen this.' The defendant picked up the airway and threw it into the hall of the hospital." The remarks of the one and the action of the other are both understandable under the circumstances!

In this case, the anaesthesiologist was not sued, and the surgeon was held liable by both trial and appellate courts. This case, like a Manitoba case of 1949 (27) where a surgeon was successfully sued as the sole defendant following the loss of a foreign body in the throat, proves nothing of itself regarding the subject at hand. It will be noted further that, in the Colorado case, the surgeon was helc responsible directly, not vicariously liable for the anaesthetist.

Several cases could be cited in which the action aganst the surgeon anc anaesthesiologist was unsuccessful, and where the Court did not feel obliged tc consider the question of the liability of the surgeon for the negligence of thi anaesthetist although realizing that the question existed. An example would be : New Jersey case in 1957 (28).

We have thus the following positive evidence for the idea of the surgeon a legal master of the anaesthetist: first, the case of the nurse anaesthetist; second one English case in 1951 (23); third, the doubtful authority of the Hillye case (10); fourth, one California decision of 1944 (15). Other than this, ther seems no firm authority for considering the surgeon to have vicarious respons bility for the negligent act of the anaesthetist.

\section{The Anaesthetist as other than a Legal Servant}

A fairly substantial body of authority can be brought forward to indicate the the anaesthetist is not the servant or agent of the surgeon. The principle lai down in the Hillyer case, making the surgeon responsible for the hospit: employees, has been whittled away till little, if anything, is left $(8,9)$. Thirt: five vears ago the "surgeon supreme" idea was not acceptable to a South Africa 
Court. Chief Justice Innes said that the nurses "are subordinate to the surgeons, but they are in no way their servants. The surgeon is not responsible for what the nurse does, in the sense that the master is responsible for the servant. The surgeon does not insure that he will be responsible for every misfeasance of the nurse" (29).

A 1941 Ontario case (30) is relevant although the anaesthetist was not cirectly concerned. An assistant surgeon used alcohol to cleanse the skin, p:ior to surgery. The surgeon applied electro-cautery, which ignited the alcohol, burning the patient. The surgeon alone was sued. Chief Justice Robertson said: "I do not think it can be said, wholly as a matter of law, that at every operation, the chief surgeon is responsible for whatever may occur there, or even that in every case he is liable for negligence on the part of an assistant. Something may depend on the character of the operation, and there may be rules ard customs among surgeons that must be taken into account. . . . No case was cited to us, in which the responsibility of the chief surgeon for the negligence of his assistant has been placed any higher than I have stated." This view was affirmed by the Supreme Court of Canada one year later (31).

Extension of the line of reasoning used in these two judgrnents suggests that if the surgeon is not, in the general case, vicariously responsible for the nurses, or his immediate assistant, his vicarious responsibility for the anaesthetist would be even more doubtful.

An Australian case of 1942 is of importance (32). A patient was being given open-drop ether when the ether bottle fell to the floor and broke, and the vapour was ignited by a nearby open-coil electric fire. As a result the patient's hand, which was hanging over the edge of the table, was burned. An action was commenced against both surgeon and anaesthetist. The trial judge non-suited the plaintiffs. The appellate court, however, held not only that there were grounds for the action, but that the anaesthetist was solely liable, and dismissed the action against the surgeon. Mr. Justice Starke said the surgeon: "was entitled to rely upon the careful administration of the ether by a skilled and competent anaesthetist. No fact was proved, which suggested that he ought reasonably to have anticipated negligence, whether wilful or accidental on the part of $P$. [the anaesthetist]." The Court also stated that "it is true enough that the operating surgeon was in charge of the operation, and could give directions to the anaesthetist or nursing staff, but they were not his servants or agents."

So far as we are aware, this was the first occasion in the Commonweallh or the United States on which the surgeon and anaesthetist were jointly sued for anaesthetic negligence, and on whic. the anaesthetist was held solely liable.

In the same year (1942), the case of Hughston v. Jost was tried before Mr Justice Hope in Ottawa. This is the precedent referred to in the introduction A patient brought an unsuccessful suit against an anaesthetist for injury resulting from the extravasation of Pentothal. The surgeon appeared as a witness and no as a co-defendant.

This was the first time in Canada that an anaesthetist had been the sol defendant in such circumstances, but we believe that too much emphasis has beer laid on this case. It has been referred to as an index that anaesthesia had "comı 
of age" as a specialty $(2,7,34)$. This may well be so, but when it is represented as authority overruling the master-servant relationship, considered to have existed in Ontario prior to that time (7), we believe it must be approached more cautiously

Our reasons for doubtıng its validity as an overrulng authority are: first, the patient could have sued any of the parties she wished-this had always been true, second: in the judgment, at least as reported in Ontario Weekly Notes, no reference whatever was made to the distribution of responsibility between surgeon and anaesthetist.

It has been suggested that since the Court did not regard the action as frivolous and vexatious litigation, this indicates that the anaesthetist was considered a responsible person This, however, was surely never in question. It has always been possible to sue the servant alone, even when he has a master. The reason actions are not usually framed in this way is the practical matter of recovering damages.

It is our opinion that the true position is not that Hughston $\mathrm{v}$ Jost extinguished a prior master-servant relationship, but that such a relationship had never existed in the first place Judicial opinion about that time was being influenced by other decisions, notably McFayden v Harvie in Ontario (30) and Gold y Essex County Council (9) in England It is possible that this influence may have had some effect on the pre-tral proceedings in the Hughston. $\mathrm{k}$. Jost case.

In a 1945 Ontarıo judgment, relating to a fatality following a spmal anaesthetic (35), Mr. Justice LeBel said:

No authonty has been cited to me that holds as a matter of law, that a physician is responsible or the negligence of the anaesthetist of his choice It seems to me that the physician has only to satisfy himself that the anaesthetsst is duly qualified with the skill and expenence necessary for the performance of the professional services he undertakes to perform. having done that, the physician or surgeon is not responsible, as a mattes of law, for any act or omission on the part of the anaesthetist.

In an unreported Britısh Columbia case of 1952, which concerned two anaes thetists and a surgeon, the Court concerned itself entirely with the anaesthetist: who was alleged to have been negligent. No reference was made to any vicarious liabulty of the surgeon $(36,24)$

An Ontario case (37) in 1955 involved an explosion which occurred while ether was being vaporized in a Flagg can with oxygen. Mr. Justice Smily of the Ontario High Court said in judgment: "It is quite clear on the evidence that Dr M. [the surgeon] in the curcumstances above mentioned could not be said to have been neglizent in any respect." The Court found for the defendant surgeon, anaesthetist, anc hospital

The next year an appeal was heard by the Ontario Court of Appeal. During the proceedings the appellants withdrew their case against the surgeon anc the hospital. The Court reversed the verdict of the lower court as to the anaesthetist (38), and this was subsequently affirmed by the Supreme Court of Canada (39).

This is the first instance in Canada of a surgeon and anaesthetist being codefendants in an action for anaesthetic malpractice in which the anaesthetist was found solely liable. It must be noted, however, that it was not laid down as a 
matter of law that the surgeon was or was not vicarıously liable tor the anaesthetist. This case was determined on evidence only.

In two English decisions $(40,41)$, the anaesthetist was held not liable. The surgeons apparently were not joined in the actions. These cases are of little help, therefore, in the present connection.

In the American courts, a case involving a nurse-anaesthetist is very much in point. A nasotracheal tube was inserted by mistake in the oesophagus and the patient sustained a perforated viscus from the pressure of the anaesthetic gases. The surgeon, anaesthetist, and hospital were joined as co-defendants. In dismissing the action against the surgeon, Mr. Justice Donworth of the Supreme Court of Washington noted:

Dr. H. [the surgeon] testrfied that Miss R. [the anaesthetist] knew considerably more about adminsteang, an anesthetic than he did, and that he left completely to her discretion the adm_nstration of the ether to the plaintiff. He also testified that all surgeons in Spokane customarly relied wholly on the nurse anesthetists or physician anesthetssts supplied by the hospitals to adminster anesthetics during surgical operatons. Three other surgeons called by Dr. H. testified to the same effect. The Court also noted.] Normally the hospital charged patients for the very services which Miss R. was rendering to the plantiff when this injury occurred.

It is too early to say tha: this represents a trend to extinguish the previously clear-cut master-servant re-ationshup of surgeon and nurse anaesthetist in most jurisdictions in the United States.

In an Ohio trial in 194» (13), which involved a broken spinal needle, Mr. Justice Doyle ruled:

Dr. W. [the surgeon] and the plaintiff entered onginally into a consensual contract. At the tıme, the parties understood that Dr. W. was not to adminster the anesthetic, but was to perform the abdominal operation. Dr. W. suggested that Dr. M. [the anaesthesiologist] be engaged No objection was interposed yy the plaintiff. The plainteff accepted the services of Dr. M, and although Dr. V\%. actually engaged Dr. M., nevertheless there was created between the plaintfff and Dr. M. a separate contract by implication. Under these circumstances, each doctor was engaged to perform his separate and distinct work, independent of the other.

By coincidence, in this case, as in the case in Ontario in 1945 (35), the surgeon participated in the anaesthetic administration by placing the needle intradurally, after an unsuccessful attempt by the anaesthetist. In neither case was it inferred that this alone rendered him liable for the anaesthetic or the actions of the anaesthetist.

In considering an action arising out of a cyclopropane explosion, Mr. Justice McBride of the Court of Appeal of Louisiana said in 1955 (44):

There was no negligence or lack of skill or competence on the part of Dr. O. [the surgeon]. ... There is no substance in the averments that he selected the wrong type of anesthetic, or that the instrumentalities used to administer it were under his control, or that he had control of or su jervision of the anesthesiologist, or the equi ment, nor can it be said that he was guil y of selectmg an incom Jetent anesthesio_og_st, for the record shows that he had nothing to do with tae choice o_ Dr. D. [the anaesthesiologist" but rather Dr. D. was selected by the anesthesiological staff of Foundation Hospital. It is true that Dr. O., at one point in his testumony, said that he had done nothing to 
prevent the explosion, but we are satisfied with his subsequent explanation, that the operating surgeon is not required to do anything except to make sure that he is garbed in the proper and conventional operating room clothing.

In a 1956 Indiana case, which resulted from a post-spinal, cauda equina syndrome, Mr. Justice Bowen said:

There is no evidence upon which a reasonable inference could be based, that Dr. T. was administering such anesthetic under the control and drection of Dr. McD. [the surgeon]. ... There is nothing in the evidence, from which an inference could be based, that Dr. T. was not in complete charge of the giving of the anesthetic. ... The cases uniformly hold that a surgeon is not liable for the negligence of an anesthetist, unless such negligent acts of such anesthetst are committed under such corcumstances as impose a duty on the surgeon to correct the anesthetsst. . . To hold Dr. McD. liable under the crrçumstances shown by this record would establish a rule of law that would make a doctor lable for the reports of a pathologist, who has told a patient that a tissue is cancerous or bengn, and for all of the acts and recommendations of other types of similar specialists whose recommendations and acts are in no way subject to the dominion and control of the surgeon.

In a cross-circulation operation for open-heart surgery, the intravenous bottle to the donor patient became empty. This was alleged to have resulted in cerebral damage to the patient. In an action arising out of tnis mishap (46), District Judge Devitt ruled:

And even assuming that $\mathrm{L}$ [the chief surgeon] was "surgeon-m-charge" or "Captain of the Ship," as urgec, does it follow that he is responsible for the negligence, if any, of an anesthesiologist such as $\operatorname{Dr} X$, assigned to the case by his own superior, exercising his own s jecial medical knowledge in performing his duties without any specific drections irom L. I don't think so. . . to extend the doctrme of respondeat superior to such a situation would be to strain the doctrne beyond the basis for its creation ... There is no evidence that L. en zaged or directed Dr. X. or any of the others in the operating room, or that he had tie authority to do so The evidence is to the contrary.

A Florida appeal case, in 1958, resulted from an accident during laryngoscopy, following which two false teeth had to be removed from the lung with a bronchoscope (47). Mr. Justice Thomas said in ruling on this case: "The surgeon may have been generally in command from the beginning of the operation to the end, or as the appellants term him in the brief, 'Captam of the Ship,' but it is clear to us that he and the anesthetsst [a physician] were working in highly expert fields, peculiar to each, and that despite the common goal, the successful repair of the patient's ulcer, their responsibilities were not inextricably bound together."

A degree of caution must be used before applying the reasoning expressed in the American citations too freely to analogous situations in Canada. American and Canadian law, although similar, are by no means identical. A careful reading of the judgments mentioned indicates that British and Caradian courts are perhaps less likely to find for the plaintiff, than are their counterparts in some American urisdictions.

As Lorc Justice Denning put it in the celebrated Roe and Woolley case (41):

These two men have suffered such terrible consequences, that there is a natural feeling they should be compensated. But we should be doing a disservice to the community at 
large if we were to impose liability on hospitals and doctors for ever thing that happens to go wrong. Doctors would be led to think more of their own sa ety, than the good of the patients. Initratıve would be stufled and confidence shaken. ... We must insist on due care for the patient at every point, but we must not condemn as negligence that which is only misadventure.

Companson of this with some of the American judgments indicate that, in some jurisdictions, the courts take a much less liberal view when considering injury sustained during an operation.

\section{Liability of the Aivaesthetist for Surgical Negligence}

As mentioned earlier, the patient most often makes his prime contract with the surgeon, and a collateral contract is subsequently made with the anaesthetist. Sometimes, however, the situation is reversed and the anaesthetist is considered to be in charge, and engages the surgeon on behalf of the patient.

All the relevant decisions are American and date back quite a few years $(43,48,49,50)$. Reading these judgments indicates that the same principles apply as in the more comrnon situation where the prime contractor is the surgeon. The anaesthetist is not ordinarily responsible for the negligent acts of the surgeon. The words of Mr. Justice Sayre (49) are representative when he ruled:

[the] surgeon did perform the operation, proceeding upon his own judgement, as to what ought to be done and how. . . . The defendant took part only to the extent of administernng the anaesthetic. ... There is no suggestion that, in these things, he showed any lack of skill or committed any error, nor is there any suggestion, in pleading or in proof, that the defendant negligently advised the employmenit of an unskilful or incompetent surgeon to perform the operation. Under these circumstances the defendant was not responsible for any default of the operating surgeon, who was practising his profession as an independent agent.

\section{SetTlements}

To this point, we have relied entirely upon court decisions to make the point that the surgeon and anaesthetist are not ordinarily responsible for each other's negligent acts. We will all be aware of settlements made, before trial, where the plaintuffs intended to implicate only the surgeon or the anaesthetist, following some mishap during an speration. We must point out that a settlement does not have any legal force. It is useful however, as an indication that counsel expected a judgment would be rendered against the defendant if the case had gone to trial.

\section{DeLimitation of Responsibiutties}

In the operating room the surgeon concerns himself with the surgical procedure and the anaesthetist with the administration of the anaesthetic. This much is clear. However, there are situations in which it is difficult to determine exactly who has the prime responsibility. This is because of a wide variation of operating room custom and practice across the country. An example of one of these doubtful areas would be the posturing of the patient. This might conceivably be the business of the surgeon, the anaesthetist, or the ancillary personnel. 
In attempting to analyse who is responsible for what, some general principles may be laid down.

First, in a malpractice action, the Court would attempt to discover the relevant customs and usage among physicians, from the evidence, particularly from expert testimony. From this, the Court would determme whether a particular defendant's actions were those of a reasonable and prudent man.

Second, as put by Circuit Judge Baker in an Illinois court in 1912:

Two physcians, mdependently engaged by the patient, and serving together by mutual consent, necessarly have the right, in the absence of instructions to the contrary, to make such a division of services as, in their honest iudgennent, the circumstances may require. . . E Each, in serving with the other, is nghtly held answerable for his own wrongful conduct, and as well for all the acts or omissions of the other which he observes and lets go without objection, or which in the exercise of reasonable diligence, under the circumstances, he should have observed. Beyond this, his liability does not extend. (48)

Furthermore, everyone in the surgical team is expected to exhıbit reasonable care and act in a reasonably prudent manner. Thus, if anyone observes, or should observe, something constituting a hazard to the patient, he would be under a duty to take steps to have it remedied. This applies whether it is within his own immediate province or not, and rejardless of his status in the team

The question of whether he coulc reasonably be expected to recognize a hazard as such would have to be determined from the evidence. The experience and training of the defendant would be a consideration Thus, the anaesthetist could not reasonably be expected to recognize as such a cas eless act of the surgeon if it were of a highly technical nature, obvious though it might be to another surgeon. However, he could be expected to recognize as a dangerous act something which should be apparent to any physician. Nurses and orderlies too have responsibility as reasonable persons. The extent of their responsibility is, of course, less than that of physicians, because of the greater training and experience of the latter.

Third, if one owes the patient a direct duty of care, one does not elıminate this duty by delegation to another person.

Fourth, once a person undertakes a task, he must bring to it the requisite skill and knowledge and perform it with reasonable care. Thus, if the anaesthetsst undertakes to position the patient, or apply a tourniquet, he accepts much of the responsibility should the patient be injured thereby.

Lastly, it has been our experience that dispute between the surgeon and anaesthetist about the anaesthetic or surgical technique is fortunately very rare. Consideration of such a situation is nevertheless valuable, as it sheds light on the relative disposition of responsibility.

The primary purpose of the operation is the surgical procedure; the surgeon is the prime contractor. This may lead to the mistaken notion that the surgeon's opinion must prevail as to details of the anaesthetic technic ue. This is not so. Independent of the prime contract is the collateral contract setween the anaesthetist and the patient, regarding the administration of the anaesthetic. The notion that the surgeon has the prime duty of care with regard to the anaesthetic, and delegates this to the anaesthetist, is incorrect. 
Thus, if prior to operation, the surgeon adamantly demands that a particular anaesthetic technique or agent be used, and if in the opinion of the anaesthetist the course of action he is asked to follow is absolutely contraindicated, then only one course of action is open to the anaesthetist-he must withdraw from the case. This is not the place to enter into the implications of withdrawal, suffice tt to say that the consequences of failing to withdraw at this juncture are potentially more hazardous from the legal point of view than are those implied in submitting to duress. Withdrawal will very rarely be necessary since between reasonable men a compromise can usually be effected.

The question of relative contraindication is much less clear cut. The course of action to adopt will again depend on a consideration of the best interests of the patient, and the importance the anaesthetist ascribes to the dangers inherent in the dictated technique. Carl Wasmuth has emphatically stated (51): "The professional judgement and integrity of the anesthesiologist must never be comprised, prostituted or violated." With this sturdy view, we are in complete agreement.

In considering a confluct of opinion of this nature, Mushin has suggested "that the anaesthetist should wite down, in the hospital notes, a statement of the difference of opinion and that although he is carrying out the wishes of his colleague, he is doing this as though he were a bona fide junior assistant, racting on the orders of his chief, on whose head the responsibility rests" (52). The anaesthetist misguided enough to follow this advice, and to record the fact that he acted contrary to his own expressed professional judgment, may find that he has furnished documentary evidence of his own dereliction. Murphy and Martin (2) had this to say: "The fact that the anesthesiologist ... administers the anesthetic under duress and upon instructions from a superior, would not be a defense and even the notation upon the chart of the anesthesiologist's protest would not afford him protection "We agree

We suspect that the premise on which Mushin based his advice was the fallacious notion that the anaesthetist has the prerogative of diminishing his own status at will, and thereby abridging his liability. This is not so. The disposition of responsibility and the extent of liability are matters for the court to decide, and not subject to the whim of the anaesthetist. If the anaesthetist undertakes to administer the anaesthetıc, he alone is responsible, and he alone will be liable if he chooses to accept as an order, irresponsible or fatuous direction, even where it is delivered with every pretension of authornty This applies just as rigorously where the anaesthetist is in some degree subordmate to the surgeon

During the operation, the anaesthetist cannot withdraw from the case. If ordered by the surgeon to do something, which in the opinion of the anaesthetist would be contrary to the best interests of the patient, there is but one proper course of action, from the legal point of view-refusal.

Where a conflict of opinion and interest develops between the surgeon and anaesthetist, and an impasse is reached, either may safely proceed in his own province, once he has put the other on notice. For example, if the patient's condition is deterioratung, the anaesthetist may have to advise the surgeon that the procedure should be abbreviated or terminated, to save the patient's life. $\mathrm{He}$ should give his reasons for this opinion. The surgeon, using his professional judgment, must assess this information, apply it to the over-all circumstances, 
and act accordingly. If he decides to take the risk and continue, the anaesthetist has fulfilled his duty to the patient by putting the surgeon on notice.

In the same way, the surgeon may put the anaesthetist on notice, by objecting to some detail of the a 1aesthetic technique. If the anaesthetist, having weighed the relative risks, decices to maintain his existing course of action, the surgeon has fulfilled his duty, and if the patient sustains injury, the anaesthetist would be solely liable, providing negligence could be proved.

For one person to put another on notice in this way, it is essential that the caution be given formally, in such a way as to make it clear that it is a definite warning. The notice must not be couched in casual terms.

The question is sometimes raised as to the best course of action in an emerzency situation, where withdrawal is impossible without thereby endangering the Jatient's safety. The same principles apply. Each individual must proceed in ais own area, in accordance with his professional o jinion, if necessary putting the other on notice. In doing so, he fully discharges is duty.

Happily, the unpleasant situations outlined above almost never occur. In practice, personal, political, professional, and ethical factors impose themselves on the legal considerations. We feel, nevertheless, that the anaesthetist and surgeon should be aware of their legal position. Armed with this knowledge, there is no reason for one to attempt to force the other to adopt an unreasonable course of action; there will in fact be no grounds for dispute.

The question of disputation has been treated above in terms of its cold legal background. The authors hold views diametrically opposed to those expressed by Professor Mushin, in the one respect mentioned. It must be pointed out that his words have been taken out of context, and apart from the unfortunate legal advice he offers, he treats this matter in a very practical way. Readers are also referred to a relevant annotation in Lancet (53) and a letter to the editor of that journal, written by Pask (54).

The view that the surgeon is responsible for everything in the operating room is seen to have little support in.the deliberations of the courts. The converse view that the surgeon is responsible only for what goes on in the surgical field, and the anaesthetist for everything else, is equally fallacious. If the surgeon and anaesthetist are to pay proper attention to their own work, they cannot concern themselves with the detailed supervision of the whole operating room. At the same time, their responsibility is not strictly limited to what they do themselves. The yardstick for assessing their conduct will always be that of the "reasonable man."

\section{Mantfestly Hazardous and Whongful Conduct of a Colleague}

Ordinarily two physicians serving together are not responsible for each other's acts or omissions, yet it has been said: each "is rightly held liable . . . for all the wrongful acts or omissions of the other, which he observes and lets go without objection, or which in the exercise of reasonable duligence, under the circumstances, he should have observed" (48). These statements may appear to conflict. However, we believe the contradiction is only apparent. 
The surgeon and anaesthetist develop independent and parallel contracts with the patient in regard to their own spheres of activity. In addition, each, as a reasonable man, owes a duty to the patient covering all phases of the operation. Each engages in his own phase and may ordinarily assume that the other is competent. Such an assumption cannot reasonably be made, if one knows, or ought to know, that the other is incompetent or is acting in a reckless manner. Failure of one to intervent on the patient's behalf, in such circumstances-for example, where the other was obviously intoxicated-would be a breach of direct duty, and hence might amount to negligence. This would apply even if the incompetent person were the more senior member of the team.

The only reported instance of this sort, known to us, was a very recent criminal case in England (55). A consultant anaesthetist had become addicted to drugs, and on the occasion in question, he was administerng "Iluothane" to himself, as well as to his young, patient. An oxygen tank ran out. The child suffered a cardiac arrest and diec a month later as a result. The anaesthetist was found guilty of manslaughter.

The fact that only the anaesthetist was held criminally liable does not mean that the parents of the child would have no civil remedy against the other people involved, some of whom had known of this unfortunate man's weakness before the disaster. In circumstances of this kind, the associates of the anaesthetist and the administrative authorities concerned might be held to have breached their duty to the patient, in that they failed to suspend the anaesthetist from duty when it became apparent he was acting in a wrongful manner

\section{The Spectalist Certificate}

The view has been propounded that the surgeon is responsible for the anaesthetist if the latter is uncertified, but not responsible if he holds the Specialist Certificate. This is not correct. The law does not recognize the certificate of the Royal College of Physicians and Surgeons of Canada. It does, however, give recognition to the fact that some physicians are specialists, while others are not. To quote Judge Advocate Schroeder (38): "Every medical practitioner . . . is bound to exercise that degree of care and skill, which could reasonab y be expected of a normal, prudent practitioner of the same experience and standing, and if he holds himself out as a specialist, a higher degree of skull is required of him than of one who does not profess to be so qualified by special training and ability." Jetter puts it this way (56): "Any physician can, so far as the aw is concerned, practise as a specialist, regardless of the exten of his trainin $\not$ and knowledge. ... In other words, the specialist assumes the risk of the designation, in return for its awards."

The possession of a specialist certificate will not protect the anaesthetist ag,ainst charges of negligence if he has failed to bring to a task the requisite skil. and knowledge. Its possession, however, is evidence that he has attempted to fit himself for the task he undertakes. On the other hand, if he does not possess a certificate, but does possess the requisite skill and knowledge and undertakes 


\section{The Surgeon Chooses the Anaesthetist}

It will be remembered that where the surgeon chooses the anaesthetist, the former "has only to satisfy himself that the anaesthetist is duly c ualified with the skill and experience necessary for the performance of the processional services he undertakes to perform," as Mr. Justice LeBel put it (35). If the surgeon knowingly chooses an incompetent anaesthetist and the patient suffers damage at the latter's hands, both will be direetly liable. The surgeon will not be liable because the anaesthetist was negligent, but because he failed in his own direct duty to the patient by referring the latter to a person of inadequate ability. It is important to note the use of the word "satisfy." This does not imply any guarantee or absolute warranty of competence, merely a reasonable degree of care in the choice of anaesthetist.

\section{Anaesthetist Not Chosen by the Surgeon}

In the larger Canadian hospitals, it has become common practice for the chief of the anaesthetic department to allocate the ancesthetic duties, thus relieving the surgeon of the necessity of arranging for an anaesthetist. It seems fair to say that under these circumstances, the surgeon would be even less responsible for the competence of the anaesthetist than he would be if he chose the latter himself.

Where two doctors have a common patient, neither has to ensure that the other is competent. In the very large hospitals, surgeons and anaesthetists collaborate, who are completely unknown to eadh other. The fact that each has been accorded working privileges in the hospital would constitute reasonable grounds for the assumption by each that the other is competent, in the absence of any evidence to the contrary.

\section{ConClusions AND SUMmary}

The manner in which the surgeon and the anaesthetist develop an implied contract with the patient has been outlined. The prime contract is made with the surgeon as to the surgical procedure, and an independent collateral contract is developed with the anaesthetsst as to the anaesthetic administration.

The widely held belief that, in the general case, there is a legal or contractual relationship between the anaesthetist and surgeon is incorrect. The relationship between them is comprised of other factors. This is indicated in Figure 1. The relationship developed between them has always been decided on evidence, in each case coming to trial in the past; not as a matter of law, but on matters of fact.

The legal background of negligence, including duty of care and the difference between direct and vicarious liability, has been considered. In contemplating vicarious liability the understanding of what is implied by "control" is crucial. As Friedman puts it: "Whether the physician exercises it or not, it is his right of control which may be the deciding factor on the issue of his liability" (57). Numerous judgments have been cited from Canadian, British, Australian, and 


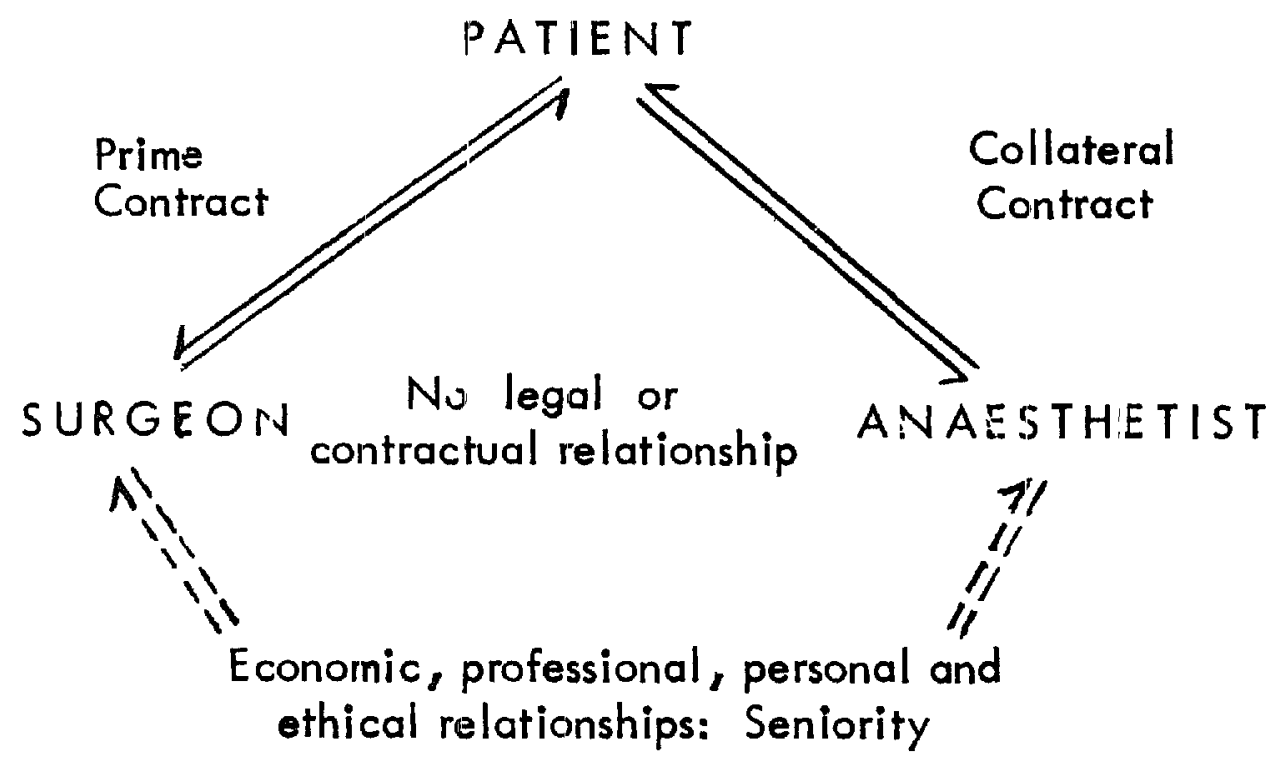

Figure 1

(Suggested by Carl Wasmuth)

American sources indicating that the surgeon and the anaesthetist are, not liable for each other's acts and omissions. Although they are persons with a common purpose, serving a common patient, they work in highly expert fields, peculiar to each, and their responsibilities are not inextricably bound together. These citations indicate that there are no grounds for believing that there is, or ever was, a legal master-servant relationship between surgeon and anaesthetist. They further indicate that the notion that the surgeon delegates a duty with regard to anaesthesia to the anaesthetist is correct only where it applies to a nurse anaesthetist. If there were any substance to this concept, the surgeon would have been found liable in each of the cases cited since delegation of such a direct duty would not have extinguished the surgeon's duty of care. Thus, in the general case, the surgeon has neither a direct nor a vicarious responsibility with regard to anaesthesia.

A number of other popular fallacies have been discussed in passing. Among these: the concept that the surgeon is responsible for everything that happens in the operating room; the concept that the anaesthetist is res sonsible for everything in the operating room, other than the surgical field, the notion that the physician's liability is limited to what he does with his own hands.

An attempt has been made to discover the principles governing the disposition of responsibility between different members of the surgical team, in this connection, the question of disputation between surgeon and ariaesthetist has been treated at some length. The authors disagree with Mushin's views as to the best manner to act if disagreement occurs, and venture to offer some advice of their own. We feel that if the legal responsibilities of surgeon and anaesthetist were more exactly appreciated than they are at present, the likelihood of argument would be diminiṣ̣ed. 
If each duly appreciates that the other must not breach his own duty of care to the patient, an amicable working agreement can readily be achieved since neither is then likely to attempt to force the other into conduct contrary to his expressed professional opinion.

It has been pointed out that if a physician chooses to accept, as an order, a demand which, in his professional judgment, is wrongful, he remains solely liable for his own acts or omissions. It will be no defence to plead that he committed the wrongful act under protest.

In the future, as in the sast, a surgeon expressing a preference for a particular anaesthetic technique is Lkely to find that a polite request, implying as it does, recognition of the anaesthetist's proper domain, will more likely meet with agreement than will a peremptory demand.

This paper has dealt with the impersonal legal implications relating to a professional connexion of the closest sort. In practice, it will not be their legal relationship, or rather the lack of it, which will chiefly govern the dealings between two physicians, but rather those other considerations which ordinarily regulate human affairs, and which bear on therr mutual purpose. Each must, within his own field, fulfil his duty to the patient, as his own professional conscience shall dictate. The best interests of the patient will be secured, where each, in serving with the other, uses his professional skill in such manner as will best enable his colleague to perform his part of the task. Should one engage in undue harassment of a colleague, this happy alliance must necessarily falter in its purpose.

\section{ACKNOWLEDGMENTS}

In the preparation of this paper, Dr. Carl Wasmuth of Cleveland, Ohio, offered much helpful advice, doubly valuable because of his unique position as a practising anaesthesiologist with legal training. Among others to whom we are indebted, we would mention Dr. K. G. Gray, Q.C., Dr. Fred Evis, and Dr. R. A. Gordon of Toronto; Dr T. L. Fisher and Dr. J. H. B. Hilton of Ottawa; Mr. Richard McCauley, Attorney and Counselor at Law of Atlanta, Ga, Mr. John Green, Q.C, of Regina, Dr. H. B. Graves of Vancouver, Mr P. H. Maguire, Q C, Mr. E. V Wahn, D.H.A, Mr Eric Diehl, and Dr. K. B. Lazarus, of Saskatoon, Miss E Bell, Librarian of the College of Law, University of Saskatchewan; Mr. Pete Estrada and Mrs. Helen Ruhl, Librarians of the Maricopa County Law Library, Phoenix, Ariz.

\section{RéSUMÉ}

Nous avons décrit la façon pour le chirurgien et pour l'anesthésiste de créer une entente implicite avec le malade. Le premier contact s'opère avec le chirurgien concernant les détails opératoires et une entente collatérale indépendante se fait avec l'anesthésiste en ce qui concerne l'anesthésie.

La croyance répandue que, en général, $i$ existe, entre le chirurgien et lanesthésiste, un rapport légal ou contractuel n'est pas exacte. Le rapport qui existe entre eux concerne d'autres facteurs. La figure 1 l'indique. 
Le rapport qui existe entre eux a toujours été accepté comme évident, dans le passé, dans tous les cas qui ont conduit au procès, non pas comme matière de loi, mais comme matière de fait.

Nous avons tenu compte du terrain légal de négligence, y compris le devoir de soins et la différence entre la responsabihté directe et vicariante. En parlant de responsabılité vicarıante, la compréhension de ce qui est impliqué dans le "contrôle" est cruciale. Annsi s'exprime Friedman: "Que le médecin l'exerce 'ou non, c'est son droit de contrôle qui peut être le facteur déterminant de l'étendue de sa responsabilité" (57).

Nous avons cité de nombreux jugements de sources canadiennes, anglaises, australiennes et américaines attestant que le chirurgien et l'anesthésiste ne sont pas responsables des actes et des omissions de l'un et de l'autre. En dépit du fait qu'ls soient des personnes visant un but commun, au service du même malade, ils travallent dans des domaines très spécialisés, particuliers à chacun, et leurs responsabilités ne sont pas hées de façon inextricable. Ces citations nous indiquent qu'il n'y a pas de bien-fondé pour croire qu'il y a ou qu'il y a eu de rapport légal de maître à serviteur entre le chirurgien et l'anesthésiste. Ces citations laissent entendre de plus que la notion que le chirurgien délègue ses devoirs à l'anesthésiste en ce qui regarde l'anesthésie n'est exacte que s'il s'agit d'une infirmière anesthésiste. S'll avait exîsté substance à un tel concept, le chrrurgien aurait été tenu responsable dans chacun des cas cités puisque la délégation d'un tel devoir direct n'aurait pas exclus le devoir de soins du chirurgien. Ainsi, dans le cas ordinaire, le chirurgien n'a ni une responsabilité directe ni une responsabilité vicariante en ce qui concerne l'anesthésie.

En passant, nous avons discuté un nombre d'autres faussetés populaires. Entre autres choses la croyance que le chrurgien est responsable de tout ce qui peut arriver dans la salle d'opération, la croyance que l'anesthésıste est responsable de tout ce quı arrive dans la salle d'opération, en dehors du domaine chirurgical; la croyance que la responsabilité du médecin est limtée à ce qu'il fait de ses propres mains.

Nous avons essayé de découvrır les principes régissant le partage de la responsabilité des différents membres de l'équipe chirurgicale, à ce point de vue, la question de conflit entre le chirurgien et l'anesthésiste a été exposée plus longuement. Les auteurs diffèrent d'opınion avec Mushın sur la meilleure façon d'agir s'il existe un désaccord entre les deux et lls vont même jusqu'à donner leurs conseils personnels. Nous avons la conviction que si les responsabilités légales du chirurgien et de l'anesthésiste étaient plus exactement précisées qu'elles re le sont dans le moment, l'attitude de conflit serait diminuée.

Si chacun évaluait exactement que l'autre ne doit pas modifier son devoir de soins au malade, une er tente amicale de travail pourrait exister, puisque ni l'un ni l'autre n'essaierait ce forcer l'autre à agir contrairement à l'opinion professionnelle qu'il exprims.

Il a été démontré quə si un médecin choisit ou accepte comme un ordre une demande que, dans son jugement professionnel, il estime fausse, il demeure entièrement responsable de ses actes et de ses omissions. Il n'y aura pas de défense à plaider qu'il a commis un acte à tort comme protêt. 
A l'avenir comme par le passé d'ailleurs, un chrurgien qui manifeste une préférence pour une technique anesthésique se rendra à l'évidence qu'une demande polie, supposant comme elle le fait, la reconnaissance du domaine propre de l'anesthésiste, sera plus susceptible de recevoir une adhésion qu'une demande péremptoire.

Dans cet article, on a discuté des aspects légaux impersonnels en relation avec une situation professionnelle des plus rapprochées. En pratique, ce ne sera pas l'existence ou l'absence de leur statut légal qui présidera au commerce entre ces deux médecins mais plutôt d'autres considérants qui régissent ordinairement les affaires humaines et qui influencent leurs intentions réciproques. Chacun doit, dans son propre domaine, remplir son devoir envers le malade, comme le lui dicte sa conscience professionnelle. Ainsi seront sauvegardés les meilleurs intérêts du malade lorsque chacun, en collaboration avec l'autre, se sert de sa dextérité professionnelle pour permettre à son collègue de réaliser sa part de devoirs. Si quelqu'un acquiesçait à la soumission indue d'un collègue, cette heureuse alliance laisserait nécessairement planer des doutes sur son but.

\section{REFERENCES}

1 Loro Nathan. Medical Negligence 1st. ed. London Butterworth (1957)

2. Murphy, J. D., \& Martin, S. J Malpractice as Relatedi to the Anesthesiologist. Anesthesiology 20. 99 (1959).

3. Wasmutr, C. E. Legal Pitfalls in the Practice of Anesthesia. Anesth. \& Analg. 37: 385 (1958).

4. Meredrth, W. C. J. Malpractice Liability of Dogtors and Hospitals. Toronto. Carswell (1956)

5. Hayr, E, et al Law of Hospital and Nurse. 1st ed. New York. Hospital Textbook Company (1958)

6. Gray, K. G. Law and the Practice of Medicine 2nd ed Toronto: Ryerson (1955).

7. Hilton, J H. B. Medicolegal Aspects of Anaesthesia C M A J 69. 641 (1953).

8 Cassidy v Ministry of Health Fahrm, Third Party [1951] ] All E R. 574.

9. Gold v. Essex County Council [1942] 2 All E.R. 257.

10. Hillyer v Board of Governors of St Bartholomew's Hospital [1909] 2 K B. 820.

11. Schloendorff v Society of the New York Hospital, 105 N E. 92 (1914) N.Y.

12. Payne, D. J. The Tort of Negligence. Current Legal Problems 6 236. London. Stevens (1953)

13 Wiley $\mathrm{v}$. Wharton et al, $41 \mathrm{~N}$ E $2 \mathrm{~d} 255$ (1941) Ohıo

14. Wrimss, G The Defence of Necessity Current Legal Problems 6216 London: Stevens (1953).

15. Ybarra v. Spangard et al, 154 P. 2d. 687 (1944) Cal.

16. Aderhold v. Bishop, 221 P. 752 (1923) Okla.

17. Mahon v. Osborne [1939] 1 All E.R. 535.

18. Beadles v. Metayka, 311 P. 2 d 711 (1957) Colo.

19. Chalmers-Francis v. Nelson, 57 P. 2d. 1312 (1936) Cal

20 Cavero v. Franklin General Benevolent Society, $214 \mathrm{P} 2 \mathrm{~d} 854$ (1950) Cal.

21. Jackson v Joyner, $72 \mathrm{~S}$ E. 2 d. 589 (1952) N.C.

22. Tarrow, A. B. Medico-legal Aspects of Anesthesiology. Anesth. \& Analg 36. 64 (1957).

23 Jones v. Manchester Corporation et al. [1952] 2 All E R. 125;

24. Burk v S, B and K. [1951] 4 W. W. R. 520 B.C

25. Fisher, T. L. A Legal Pot-pourr. C.M.A J. $70: 576$ (1954).

26. Bernsden v. Johnson, 225 P. 2d. 1033 (1953) Kan.

27. Anderson v. Chasney et al. [1949] 4 D. L. R. 71 Man. 
28 Ayers v. Parry, 192 F. \&d. 181 (1951) N.J.

29 Van Wyck v. Lewis South Africa (1924). Quoted by Nathan (1).

30 McFadyen v Harve [1941] 2 D. L R. 663 (Ontano Court of Appeal).

31 McFadyen v Harvie [1942] 4 D. L. R. 647 (Supreme Court of Canada).

32. Paton v. Parker, 15 Aust Law I. 285 (1942).

33 Hughston v Jost [1943] O. W N. 3 Ont.

34 Graves, H. B. The Medico-legal Responsibilities of the Anaesthetist. Canad Anaesth Soc J. 4428 (1957).

35. Walker $\mathrm{v}$ Bedard and Snelling [1945] 1 D. L. R. 529 Ont.

36. Burk v Starr et al. (unreported), Supreme Court of Bntısh Columbia (1952).

37 Crits v Sylvester et al (Ontario High Court) [1955] 3 D L R 181

38. Crits and Crits v. Sylvester et al (Ontario Court of Appeal) [1956] 3 D L Z. (2d) 502.

39 Sylvester v. Crits et al (Suprene Court of Canada) [1956] 5 D. L. R. (2C) 601

40. Crawford v. Charing Cross Hospital. B. M. J 1i: 1329 (1953), Lancet 11. 1320 (1953).

41. Roe $\mathrm{v}$ Ministry of Health. Woolley v. the same [1954] 2 All E.R. 131.

42. Kemalyan $\mathrm{v}$ Henderson, $277 \mathrm{P}$ 2d. 372 (1954) Wash.

43 Lawson v Crane and Hall, 74 Atl. 641 (1909) Vt.

44 Andrepont v Ochsner, 84 So 2 d 63 (1955) La

45 Huber v. Protestant Deaconess Hospital Association, 133 N E. 2 d 864 (1956) Ind.

46. Thompson v. Lillehei et al, 164 F. Supp. 716 (1958) Minn.

47 Dohr et al. v. Smith et al., 104 So. $2 \mathrm{~d} 29$ (1958) Fla.

48. Morey v. Thybo, 42 L. R. A. (N.S ) 785 (1912) Ill.

49 Robinson v. Crotwell, 57 So. 23 (1912) Ala.

50 Jett v Linville, $259 \mathrm{~S}$ W. 43 (1924) Ky.

51. Wasmuth, C E. Personal cornmunication.

52 Muswin, W. W. Medico-legal Aspects in Anaesthesia. Anaesthesia 9. 232 (1954).

53 Annotation Lancet in. 1080 (1953)

54 PASK, A E Letter to the Editor. Lancet 1. 1101 (1953)

55 The Times, London, England, February 21, 1959.

56. Jetten, W W. Civil Malpractice Basic Principles. Med Clin N Am, Sept. 1953: 1565.

57 Friedman, G A Ancsthesiology and the Law Med. Times 83. 925 (1955). 